\title{
Management of Volunteer Castor Bean in the Glyphosate- Resistant SOYbean CROP ${ }^{1}$
}

\author{
Manejo de Mamoneira Voluntária na Cultura da Soja Resistente ao Glyphosate \\ ROCHA, V.S. ${ }^{2}$, COSTA, A.G.F. ${ }^{3}$, TROVÃO, D.M.B.M. ${ }^{2}$, ZONTA, J.H. ${ }^{3}$, SOFIATTI, V. ${ }^{3}$, \\ MACIEL, C.D.G. ${ }^{4}$, and ALMEIDA, H.S.A. ${ }^{5}$
}

\begin{abstract}
The goal of this study was to evaluate the management of volunteer castor bean with herbicide applications used in pre and post-seeding of soybean crop resistant to glyphosate. Two experiments were conducted in a greenhouse in a completely randomized design with three replications. The first experiment corresponded to applications of desiccation with treatments: glyphosate $\left(1,080 \mathrm{~g} \mathrm{ha}^{-1}\right)$; glyphosate + 2,4-D $\left(1,080+670 \mathrm{~g} \mathrm{ha}^{-1}\right)$; glyphosate + carfentrazone-ethtyl $\left(1,080+20 \mathrm{~g} \mathrm{ha}^{-1}\right)$; glyphosate + flumioxazin $\left(1,080+25 \mathrm{~g} \mathrm{ha}^{-1}\right)$; glyphosate + saflufenacil $\left(1,080+35 \mathrm{~g} \mathrm{ha}^{-1}\right)$; glyphosate + chlorimuron-ethyl $(1,080+$ $\left.12.5 \mathrm{~g} \mathrm{ha}^{-1}\right)$; diuron + paraquat $\left(300+600 \mathrm{~g} \mathrm{ha}^{-1}\right)$; and the control without application. In the second experiment, the treatments corresponded to doses of $0,90,180,360,720,1,440$, 2,880 and 5,760 $\mathrm{g} \mathrm{ha}^{-1}$ of glyphosate for applications in post-emergence in soybean RR. The applications took place when the castor bean plant had four to six true leaves. The evaluations done in both experiments were: control and plant height at 7, 14 and 21 days after application (DAA); and stem diameter, leaf area, root volume, dry mass of shoots and roots at 21 DAA. The treatments with diuron + paraquat and glyphosate associated with 2,4-D, carfentrazoneethyl, flumioxazin or saflufenacil are more efficient for castor bean control in desiccation in pre-seeding of soybean. Glyphosate doses from $720 \mathrm{~g} \mathrm{ha}^{-1}$ are effective to control castor bean in post-emergence of the glyphosate-resistant soybean crop.
\end{abstract}

Keywords: Ricinus communis, Glycine max, control, herbicide.

RESUMO - O objetivo deste trabalho foi avaliar o manejo de mamoneira voluntária com aplicações de herbicidas utilizados em pré e pós-semeadura na cultura da soja resistente ao glyphosate. Dois experimentos foram realizados em casa de vegetação, em delineamento inteiramente casualizado com três repetições. O primeiro experimento correspondeu a aplicações de dessecação com os tratamentos: glyphosate (1.080 $\left.\mathrm{g} \mathrm{ha}^{-1}\right) ;$ glyphosate $+2,4-\mathrm{D}\left(1.080+670 \mathrm{~g} \mathrm{ha}^{-1}\right) ;$ glyphosate + carfentrazone-ethtyl $\left(1.080+20 \mathrm{~g} \mathrm{ha}^{-1}\right) ;$ glyphosate + flumioxazin $\left(1.080+25 \mathrm{~g} \mathrm{ha}^{-1}\right) ;$ glyphosate + saflufenacil $(1.080+$ $\left.35 \mathrm{~g} \mathrm{ha}^{-1}\right)$; glyphosate + chlorimuron-ethyl $\left(1.080+12,5 \mathrm{~g} \mathrm{ha}^{-1}\right)$; diuron + paraquat $\left(300+600 \mathrm{~g} \mathrm{ha}^{-1}\right)$; e a testemunha sem aplicação. No segundo experimento, os tratamentos corresponderam às doses de 0, 90, 180, 360, 720, 1.440, 2.880 e 5.760 $\mathrm{g} \mathrm{ha}^{-1}$ de glyphosate para aplicações em pós-emergência em soja RR. As aplicações foram feitas quando a mamoneira estava com quatro a seis folhas verdadeiras. As avaliações realizadas nos dois experimentos foram: controle e altura de plantas aos 7, 14 e 21 dias após a aplicação (DAA); e diâmetro do caule, área foliar, volume de raízes, massa seca de parte aérea e raizes aos 21 DAA. Os tratamentos com diuron + paraquat e glyphosate associado com 2,4-D, carfentrazone-ethyl, flumioxazin ou saflufenacil são mais eficientes para controle de mamoneira na dessecação em pré-semeadura da soja. Doses de glyphosate a partir de $720 \mathrm{~g} \mathrm{ha}^{-1}$ são eficazes para controle da mamoneira na pós-emergência da cultura da soja resistente ao glyphosate.

Palavras-chave: Ricinus communis, Glycine max, controle, herbicida.

Recebido para publicação em 9.11.2015 e aprovado em 31.1.2016.

2 Universidade Estadual da Paraíba, Campina Grande, PB, Brasil, <viviane.roche@hotmail.com>; ${ }^{3}$ Embrapa Algodão, Campina Grande-PB, Brasil; ${ }^{4}$ Universidade Estadual do Centro-Oeste, Guarapuava-PR, Brasil; ${ }^{5}$ Universidade Federal da Paraíba, Areia-PB, Brasil. 


\section{INTRODUCTION}

Castor bean oil (Ricinus communis) has specific properties that give itself a high commercial value, with various applications in the industry. However, global consumption has been limited by insufficient production, resulting in great economic potential to expand the cultivation of castor bean plant (Campbell et al., 2014). Brazil is the fifth largest producer of castor bean, but its share corresponds to less than $1 \%$ of the total (FAO, 2015). The averages of production, cultivation area and productivity in the last five harvests were 66,000 tons, 139,000 ha and $419 \mathrm{~kg} \mathrm{ha}^{-1}$, respectively; $95 \%$ of production is concentrated in the Northeast (Conab, 2015), which is limited by the water regime and the low technology adoption.

Considering that castor bean plant produces more than $2,000 \mathrm{~kg}$ seed ha ${ }^{-1}$ (Soratto et al., 2011), Brazilian productivity is considered extremely low, demanding the improvement of their production systems to allow further expansion of cultivated area with that culture. In this scenario, coupled with the development of more productive and precocious recent genetic materials and the development of mechanized harvesting, castor bean cultivation has shown potential to regions of higher technological level, as the Brazilian cerrado, as an alternative rotation and succession (second harvest) to soybean cultivation, cotton and corn (Soratto et al., 2012).

Despite the potential to increase the area and the castor bean production, the presence of ricin toxic protein in its seed is among the greatest challenges for its large-scale cultivation. In this context, castor bean as a volunteer plant needs special attention, especially when used in rotation with food crops because the seeds produced from their infestation can mix up with the product during harvest, like soybeans, what may adversely affect the market. Therefore, the control of castor bean volunteer is necessary, as a strategy to prevent that contamination (Severino et al., 2012; Mckeon and Brichta, 2014).

In addition to depreciation risk for the harvested product, castor bean plant also has considerable capacity of competition and consequent risk of reduction in productivity and interference in the process of harvesting, when voluntarily established in annual crops. In addition, there are difficulties for its management due to numbness and quantity of seed reserves, which allow various emergency flows at different depths, including the presence of straw on the soil surface (Silva, 2013) - which is normally present in soybean crop in no-tillage system. Gordon et al. (2011) mentioned that castor bean plant can cause substantial costs for its mechanical and chemical control.

The area of transgenic glyphosateresistant soybean represents approximately $75 \%$ of the cultivation of oilseeds in Brazil. The use of varieties with this trait brought the national agriculture a new scenario for soybean crops (Rizzardi and Silva, 2014). The most widely adopted management before seeding of soybean consists of weed desiccation using isolated glyphosate and in many cases, mixed up with other herbicides such as 2,4-D and chlorimuron-ethyl. After the emergence of the crop, the most producers only used glyphosate due to the ease of use provided by this herbicide (Minozzi et al., 2014), mainly for controlling various kinds of weeds at low cost.

Considering that chemical control is the most widely used in large-scale crops, studies of control of castor bean using herbicides are needed for the development of management strategies for castor bean volunteer plants in soybean crop. According to Costa et al. (2014), among herbicides that were not selective to castor bean plant and could be used in succession crops, we can mention: isolated atrazine or in admixture with simazine or metolachlor diclosulan, 2,4-D, flumetsulan, imazaquin, imazapic, imazapyr, sulfentrazone, isoxaflutole, pyrithiobac-sodium, lactofen, fomesafen and trifloxysulfuron-sodium. In addition, Monquero et al. (2011) and Silva (2013) found efficiency on control of castor bean using saflufenacil, which can be used in desiccation (Brasil, 2015). Thus, considering the predominance of glyphosate-resistant soybean cultivation and the possibility of using this compound isolated or in combination with other herbicides, it aimed to evaluate the 
management of castor bean volunteer with applications of herbicides used in pre and postsowing of soybean.

\section{MATERIAL AND METHODS}

Two experiments were conducted in a greenhouse located at coordinates $7^{\circ} 13$ '20" S and $35^{\circ} 54^{\prime} 14^{\prime \prime} \mathrm{W}$. The first test was aimed at application in desiccation in pre-sowing, and the second at post emergence of soybeans genetically modified for resistance to glyphosate, being conducted from October to November 2014 and from March to April 2015, respectively.

The soil used as substrate in both trials was originated from topsoil from 0 to $20 \mathrm{~cm}$ from fallow agricultural area, located in Barbalha-CE, classified as Fluvisol (Embrapa, 2013), sandy-clay-sandy, whose chemical characteristics were: $\mathrm{pH}$ in water $=6.5 ; \mathrm{Ca}^{+2}=$ $155.3 \mathrm{mmol}_{\mathrm{c}} \mathrm{dm}^{-3} ; \mathrm{Mg}^{+2}=70.5 \mathrm{mmol}_{\mathrm{c}} \mathrm{dm}^{-3}$; $\mathrm{Na}^{+}=5.6 \mathrm{mmol}_{\mathrm{c}} \mathrm{dm}^{-3} ; \mathrm{H}^{+}+\mathrm{Al}=10.7 \mathrm{mmol}_{\mathrm{c}} \mathrm{dm}^{-3}$; $\mathrm{CTC}=247.7 \mathrm{mmol}_{\mathrm{c}} \mathrm{dm}^{-3} ; \mathrm{V}=96.0 \%$; $\mathrm{Al}^{+3}=0.0 \mathrm{mmol}_{\mathrm{c}} \mathrm{dm}^{-3} ; \mathrm{P}=4.6 \mathrm{mg} \mathrm{dm}^{-3}$; $\mathrm{K}^{+}=5.6 \mathrm{mmol}_{\mathrm{c}} \mathrm{dm}^{-3}$; e $\mathrm{MO}=17.0 \mathrm{~g} \mathrm{~kg}^{-1}$. Subsequently, the soil was sifted in a $2 \mathrm{~mm}$ mesh, dried in the shade, fertilized with $10 \mathrm{~kg}$ of superphosphate and $100 \mathrm{~g}$ of urea per $\mathrm{m}^{3}$ of soil and then immediately used to fill containers (vessels) with 4-liter capacity, being in the experimental plots.

The experiments were conducted in a completely randomized design with three replications. Cultivar BRS Energia was sown in both trials, with nine seeds per pot at $3 \mathrm{~cm}$ deep. Thinning was performed five days after seedling emergence, in which remained only one plant per container. Humidity was maintained by daily irrigation of $5 \mathrm{~mm}$ by a system composed of micro sprinklers with preprogrammed timer.

In the first experiment, to evaluate the effectiveness of chemical control in desiccation in soybean pre-sowing, the treatments were: glyphosate $\left(1,080 \mathrm{~g} \mathrm{ha}^{-1}\right)$; glyphosate $+2,4-\mathrm{D}$ $\left(1,080+670 \mathrm{~g} \mathrm{ha}^{-1}\right) ;$ glyphosate + carfentrazoneethyl $\left(1,080+20 \mathrm{~g} \mathrm{ha}^{-1}\right)$; glyphosate + flumioxazin $\left(1,080+25 \mathrm{~g} \mathrm{ha}^{-1}\right)$; glyphosate + saflufenacil $\left(1,080+35 \mathrm{~g}^{-1} \mathrm{ha}^{-1}\right)$; glyphosate + chlorimuron-ethyl $\left(1,080+12.5 \mathrm{~g} \mathrm{ha}^{-1}\right)$; diuron
+ paraquat $\left(300+600 \mathrm{~g} \mathrm{ha}^{-1}\right)$; and a control without application. In the second trial, the treatments were represented by eight doses of glyphosate: 0, 90, 180, 360, 720, 1,440, 2,880 and $5,760 \mathrm{~g} \mathrm{ha}^{-1}$ from the methodology described by Seefeldt et al. (1995) and from the information about recommended doses on the MALFS (Ministry of Agriculture, Livestock and Food Supply) of cultivation of genetically modified glyphosate-resistant soybean (Brasil, 2015).

The applications were conducted in post-emergence phase of the castor bean plant in a stage of four to six true leaves, using a knapsack sprayer, kept at constant pressure with $\mathrm{CO}_{2}$, equipped with boom with four low-drift flat fan nozzles 11002 , spaced $0.5 \mathrm{~m}$ apart and positioned $0.5 \mathrm{~cm}$ from the target height, using spray volume rate of $200 \mathrm{~L} \mathrm{ha}^{-1}$.

At 7, 14 and 21 days after application (DAA), height and control were evaluated. Height was obtained from the surface of the soil up to the insertion of the apical bud of the plants, and control by visual scale of percentage SBCPD (1995) in which 0\% meant no damage and $100 \%$ meant plant death. At 21 DAA stem diameter, leaf area, dry biomass of shoot, volume and dry mass of the root system, in both experiments, were evaluated. Stem diameter was measured close to the soil surface using a digital caliper. The area of the leaf was obtained by estimation from the leaf dimensions, as described by Severino et al. (2004). The volume of the root system was obtained according to Silva et al. (2006), where the roots were washed with tap water and placed in a graduated cylinder with a volume of $100 \mathrm{ml}$ containing $50 \mathrm{~mL}$ of water, and while adding the roots, it was determined the displaced water volume, being that value equivalent to the volume occupied by them. The dry biomass of shoots and roots of the plants were obtained by drying the plant material in an oven equipped with forced ventilation of air at $65^{\circ} \mathrm{C}$ for 72 hours until the reaching of constant mass, with subsequent weighing in semi-analytical scale.

Data from both experiments were submitted to analysis of variance. In the first experiment the means were compared by Tukey test at $5 \%$ of probability, and in the 
second, the doses of glyphosate were adjusted by non-linear regression, using initially the log-logistic model of four parameters:

$$
y=d+\frac{a-d}{1+(x / c)^{b}}
$$

In this model, $y$ represents the dependent variable; $x$, the concentration of the herbicide; and $a, b, c$ and $d$, the model parameters, wherein $a$ is the average of the control response, $b$ is the slope of the curve, $c$ is the concentration which provides $50 \%$ of the value of the dependent variable $\left(\mathrm{I}_{50}\right)$ and $d$ is the medium response at high doses (Seefeldt et al., 1995). For the cases of lack of adjustment to the four-parameter model, it was used the adjustment to logistical model of three parameters, which does not include the parameter $d$ :

$$
y=\frac{a}{1+(x / c)^{b}}
$$

\section{RESULTS AND DISCUSSION}

\section{Experiment 1 - Control of castor bean plant in pre-sowing soybean}

In every phase of assessment it was possible to check the effect of control of herbicide treatments (Table 1). The association of glyphosate with 2,4-D, carfentrazone-ethyl, flumioxazin and saflufenacil and the mixture diuron + paraquat, showed higher efficiency, whose percentages were above $95 \%$ at 7 and 14 DAA, reaching $100 \%$ at 21 DAA. Glyphosate applied alone or in combination with chlorimuron-ethyl resulted in lower percentages of control: between 63 and $73 \%$ in the three evaluation periods. Therefore, the best results were obtained by the combination of inhibition of enzyme EPSPs (glyphosate) with inhibition of enzyme PROTOX (carfentrazone, saflufenacil or flumioxazin) or with the mechanism of mimicry of auxin $(2,4-D)$ as well as with association of inhibitions of photosystem I (paraquat) and II (diuron). Foloni et al. (2011) found that glyphosate association with 2,4-D $\left(1,420+1,340 \mathrm{~g} \mathrm{ha}^{-1}\right)$ had a significant capacity for dehydration of castor bean when applied to the culture of desiccation in pre-harvest, with a greater effect than the application of the same single dose of 2,4-D or paraquat at $1,200 \mathrm{~g} \mathrm{ha}^{-1}$. This result is similar to that observed in this study in which the use of herbicides combined in one application can increase the control of castor bean in relation to isolated applications of certain active ingredients.

As for the height of plants, effects of the treatment were observed in all evaluations (Table 1). In general, diuron + paraquat and

Table 1 - Control (\%) and height (cm) of the castor bean plant at 7, 14 and 21 DAA of herbicides, aiming desiccation of pre-sowing

\begin{tabular}{|c|c|c|c|c|c|c|}
\hline \multirow{2}{*}{ Treatment } & \multicolumn{3}{|c|}{ Control (\%) } & \multicolumn{3}{|c|}{ Height $(\mathrm{cm})$} \\
\hline & $7 \mathrm{DAA}^{-1}$ & 14 DAA & $21 \mathrm{DAA}$ & $7 \mathrm{DAA}$ & 14 DAA & $21 \mathrm{DAA}$ \\
\hline Control with no application & $0.0 \mathrm{c}$ & $0.0 \mathrm{c}$ & $0.0 \mathrm{c}$ & $35.9 \mathrm{a}$ & $42.1 \mathrm{a}$ & $\overline{52.5 \mathrm{a}}$ \\
\hline Glyphosate & $63.3 \mathrm{~b}$ & $70.0 \mathrm{~b}$ & $73.0 \mathrm{~b}$ & $28.7 \mathrm{abc}$ & $28.6 \mathrm{~b}$ & $29.7 \mathrm{bc}$ \\
\hline Glyphosate + 2,4-D & $97.3 \mathrm{a}$ & $99.0 \mathrm{a}$ & $100.0 \mathrm{a}$ & $12.8 \mathrm{~d}$ & $13.7 \mathrm{c}$ & $17.3 \mathrm{~cd}$ \\
\hline Glyphosate + carfentrazone-ethyl & $95.7 \mathrm{a}$ & $99.0 \mathrm{a}$ & $100.0 \mathrm{a}$ & $20.0 \mathrm{~cd}$ & $18.7 \mathrm{c}$ & $16.2 \mathrm{~cd}$ \\
\hline Glyphosate + flumioxazin & $98.7 \mathrm{a}$ & $100.0 \mathrm{a}$ & $100.0 \mathrm{a}$ & $16.3 \mathrm{~d}$ & $12.0 \mathrm{c}$ & $13.3 \mathrm{~d}$ \\
\hline Glyphosate + saflufenacil & $100.0 \mathrm{a}$ & $100.0 \mathrm{a}$ & $100.0 \mathrm{a}$ & $21.7 \mathrm{bcd}$ & $18.6 \mathrm{c}$ & $15.0 \mathrm{~cd}$ \\
\hline Glyphosate + chlorimuron-ethyl & $63.3 \mathrm{~b}$ & $66.7 \mathrm{~b}$ & $67.7 \mathrm{~b}$ & $33.2 \mathrm{ab}$ & $28.6 \mathrm{~b}$ & $32.5 \mathrm{~b}$ \\
\hline Diuron+paraquat & $100.0 \mathrm{a}$ & $100.0 \mathrm{a}$ & $100.0 \mathrm{a}$ & $17.7 \mathrm{~cd}$ & $17.1 \mathrm{c}$ & $16.7 \mathrm{~cd}$ \\
\hline $\mathrm{F}_{\mathrm{cal}}$ & $112.6^{*}$ & $341.4^{*}$ & $179.5^{*}$ & $11.4^{*}$ & $30.9^{*}$ & $20.1^{*}$ \\
\hline CV $(\%)$ & 7.4 & 4.1 & 5.7 & 18.5 & 14.0 & 21.6 \\
\hline $\operatorname{DMS}(5 \%)$ & 16.2 & 9.3 & 12.8 & 12.2 & 8.9 & 14.7 \\
\hline
\end{tabular}
of soybean crop

${ }_{1} / \mathrm{DAA}=$ days after herbicide application. - Means followed by the same letter in the line does not differ significantly from each other by Tukey test $(\mathrm{p} \leq 0.05) . *$ Significant at $5 \%$ of probability; ${ }^{\text {NS }}$ not significant. 
associations containing glyphosate, except with chlorimuron-ethyl, resulted in lower height values along the evaluations, causing increasing reductions in this variable in relation to the control, which amounted, on average, to 51,62 and $70 \%$ to 7,14 and 21 DAA, respectively. For glyphosate applied alone or combined with chlorimuron-ethyl, it was possible to see intermediate values of height from 14 DAA, with reductions of the means in relation to the control of 32 and $41 \%$ at 21 DAA. However, for the other associations, at 21 DAA, only the mixture of glyphosate + flumioxazin resulted in significantly lower height value to those obtained with glyphosate alone or combined with chlorimuron-ethyl.

With respect to the stem diameter, diuron + paraquat and glyphosate associated with 2,4-D, carfentrazone-ethyl, flumioxazin or saflufenacil interfered in the development of this variable in relation to the control, with an average reduction of $52 \%$ (Table 2). For leaf area, shoot dry weight, volume and mass of roots, all herbicide treatments had a significant effect on those characteristics, with reduction of the means in relation to the control, at 98, 82, 86 and 92\%, respectively (Table 2). As for the dry mass of roots, the result obtained with glyphosate + chlorimuron-ethyl was significantly lower than those obtained with the other herbicide combinations. However, for the other features, it was not possible to see significant differences between the different treatments with chemical control (Table 3). Regarding the association of glyphosate + chlorimuron-ethyl, there was not a good control or more pronounced reduction of growth of castor bean plant (height, stem thickness and dry mass of roots), probably due to the selectivity and low phytotoxicity caused by chlorimuron-ethyl, according to the results in studies in greenhouse and in field (Sofiatii et al., 2012; Costa et al., 2014). That result indicates that the effects observed for that association about castor bean plant, in this study, are due primarily to the action of glyphosate.

Overall, despite not having been found significant differences between the isolated glyphosate and the most associations on growth characteristics of castor bean plant at 21 DAA, for the control and the height (Table 1), it was observed a greater efficiency of diuron + paraquat and glyphosate with 2,4-D, carfentrazone-ethyl, flumioxazin and saflufenacil, mainly in the first two assessments, characterized by a quicker effect of these treatments. Vitorino et al. (2012) found increased control of Ipomoea grandifolia at 28 DAA with the combination of glyphosate and saflufenacil $\left(720+28 \mathrm{~g} \mathrm{ha}^{-1}\right)$ with respect to the applied isolated glyphosate, i.e. the combination of mechanisms of action - in this case, inhibition of enzymes EPSPs and

Table 2 - Stem diameter (SD), leaf area (LA), volume of the root system (RS), dry mass of shoot (DMS) and roots (DMR) of castor bean plant at $21 \mathrm{DAA}^{1 /}$ of herbicides, aiming the operation of desiccation of pre-sowing of soybean crop

\begin{tabular}{|l|c|c|c|c|c|}
\hline \multicolumn{1}{|c|}{ Treatament } & $\begin{array}{c}\text { SD } \\
(\mathrm{mm})\end{array}$ & $\begin{array}{c}\text { LA } \\
\left(\mathrm{cm}^{2}\right)\end{array}$ & $\begin{array}{c}\text { DMS } \\
(\mathrm{g})\end{array}$ & $\begin{array}{c}\text { RS } \\
\left(\mathrm{cm}^{3}\right)\end{array}$ & $\begin{array}{c}\text { DMR } \\
(\mathrm{g})\end{array}$ \\
\hline Control with no application & $13.7 \mathrm{a}$ & $3337.0 \mathrm{a}$ & $22.2 \mathrm{a}$ & $18.2 \mathrm{a}$ & $4.0 \mathrm{a}$ \\
\hline Glyphosate & $11.1 \mathrm{ab}$ & $440.9 \mathrm{~b}$ & $4.7 \mathrm{~b}$ & $6.3 \mathrm{~b}$ & $0.8 \mathrm{bc}$ \\
\hline Glyphosate + 2,4-D & $6.2 \mathrm{c}$ & $0.0 \mathrm{~b}$ & $4.2 \mathrm{~b}$ & $1.7 \mathrm{~b}$ & $0.2 \mathrm{c}$ \\
\hline Glyphosate + carfentrazone-ethyl & $8.1 \mathrm{bc}$ & $0.0 \mathrm{~b}$ & $4.0 \mathrm{~b}$ & $1.7 \mathrm{~b}$ & $0.2 \mathrm{c}$ \\
\hline Glyphosate + flumioxazin & $6.4 \mathrm{c}$ & $0.0 \mathrm{~b}$ & $2.7 \mathrm{~b}$ & $1.3 \mathrm{~b}$ & $0.1 \mathrm{c}$ \\
\hline Glyphosate + saflufenacil & $6.2 \mathrm{c}$ & $0.0 \mathrm{~b}$ & $4.3 \mathrm{~b}$ & $1.3 \mathrm{~b}$ & $0.1 \mathrm{c}$ \\
\hline Glyphosate + chlorimuron-ethyl & $10.9 \mathrm{ab}$ & $494.0 \mathrm{~b}$ & $5.3 \mathrm{~b}$ & $7.3 \mathrm{~b}$ & $1.0 \mathrm{~b}$ \\
\hline Diuron+paraquat & $6.2 \mathrm{c}$ & $0.0 \mathrm{~b}$ & $3.5 \mathrm{~b}$ & $1.8 \mathrm{~b}$ & $0.1 \mathrm{c}$ \\
\hline F & $18.4 *$ & $89.2^{*}$ & $47.6^{*}$ & $17.1^{*}$ & $66.0^{*}$ \\
\hline CV $(\%)$ & 13.9 & 39.6 & 25.4 & 49.5 & 34.5 \\
\hline DMS $(5 \%)$ & 3.4 & 597.5 & 4.6 & 6.9 & 0.8 \\
\hline
\end{tabular}

${ }^{1 /} \mathrm{DAA}=$ days after herbicide application. - Means followed by the same letter in the line does not differ significantly from each other by Tukey test $(\mathrm{p} \leq 0.05) .{ }^{*}$ Significant at $5 \%$ probability; ${ }^{N S}$ not significant. 
PROTOX, respectively - was more effective than using only the first. However, for Richardia brasiliensis and Sida rhombifolia, the effectiveness of the mixture was higher only in the first evaluations ( 3 and 7 DAA), not being possible to see the difference between these treatments after 14 DAA. It is noteworthy that the use of herbicide different from glyphosate and with mechanism of residual effect, associated with the management of desiccation in pre-seeding of soybean, is important for the preservation of technology of soybean RR and prevention of cases of resistant weeds (Rizzardi and Silva, 2014).

\section{Experiment 2 - Control of castor bean volunteer plant in post-emergence of soybean}

The analysis of variance indicated significant differences in the rates of glyphosate on all evaluated variables, being observed adjustment of the dose-response curves using log-logistic models of three and four parameters, which are found in Figures 1 and 2. Medeiros et al. (2013) also found appropriate adjustment of doseresponse curves with trifluralin for growth characteristics of castor bean plants from those same log-logistic models.

For the control of castor bean plants, the absolute values of parameters $b$ and $c\left(\mathrm{I}_{50}\right)$ were, respectively, increasing and decreasing along the evaluations indicating increased herbicidal effect over time (Figure 1A). The dose required to promote $50 \%$ control after 7 DAA was $756 \mathrm{~g} \mathrm{ha}^{-1}$, reaching $451 \mathrm{~g} \mathrm{ha}^{-1}$ at 21 DAA. A similar situation was observed for plant height, particularly with regard to the decrease in the amount of $I_{50}$, because, to get $50 \%$ reduction in growth height, the dose of glyphosate corresponded to $795 \mathrm{~g} \mathrm{ha}^{-1}$ and $659 \mathrm{~g} \mathrm{ha}^{-1}$ at 7 and $21 \mathrm{DAA}$, respectively (Figure 1B). The tendency of stabilizing curves next to $100 \%$ control and of the smaller height values occurred between 720 and 1,440 $\mathrm{g} \mathrm{ha}^{-1}$ at 14 and 21 DAA respectively. Similarly, from control results of Commelina benghalensis, Richardia brasiliensis, Euphorbia heterophylla, Spermacoce latifolia, Ipomoea grandifolia and Conyza spp. with glyphosate at $720 \mathrm{~g} \mathrm{ha}^{-1}$ (Takano et al., 2013), it was observed that the time between 14 to $21 \mathrm{DAA}$ is required for higher expression of that herbicide effect.

Correia and Durigan (2010) found that weed control in cultivation of soybean RR is directly influenced by the dose of this herbicide, with satisfactory control with a single application of $960 \mathrm{~g} \mathrm{ha}^{-1}$ or the sequence of $480+480 \mathrm{~g} \mathrm{ha}^{-1}$ depending on the weed species. In this context, it is noteworthy that the sequential application of glyphosate in soybean RR, practice commonly adopted by the producers, represent alternative for the control
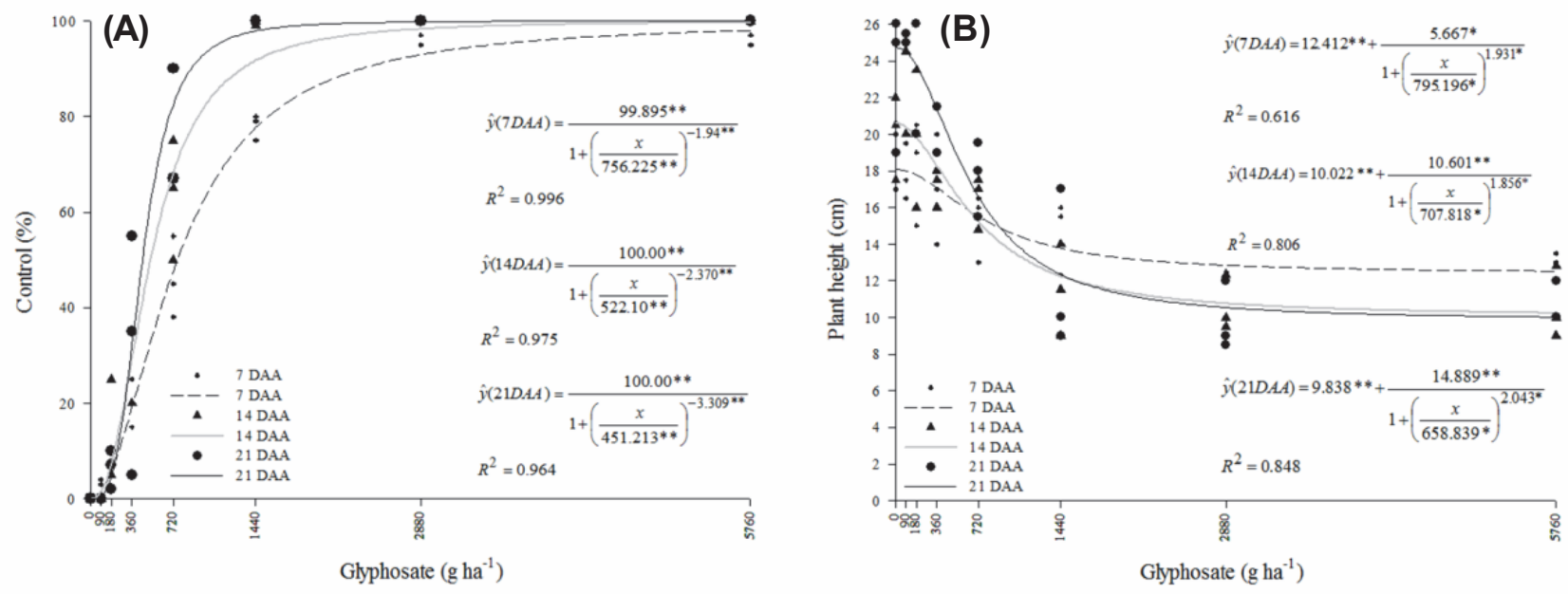

** and *: significant at 1 and $5 \%$ probability, respectively.

Figure 1 - Dose-response curves for the percentage of control (a) and height (b) of castor bean plant at 7, 14 and 21 days after application (DAA) of glyphosate. 

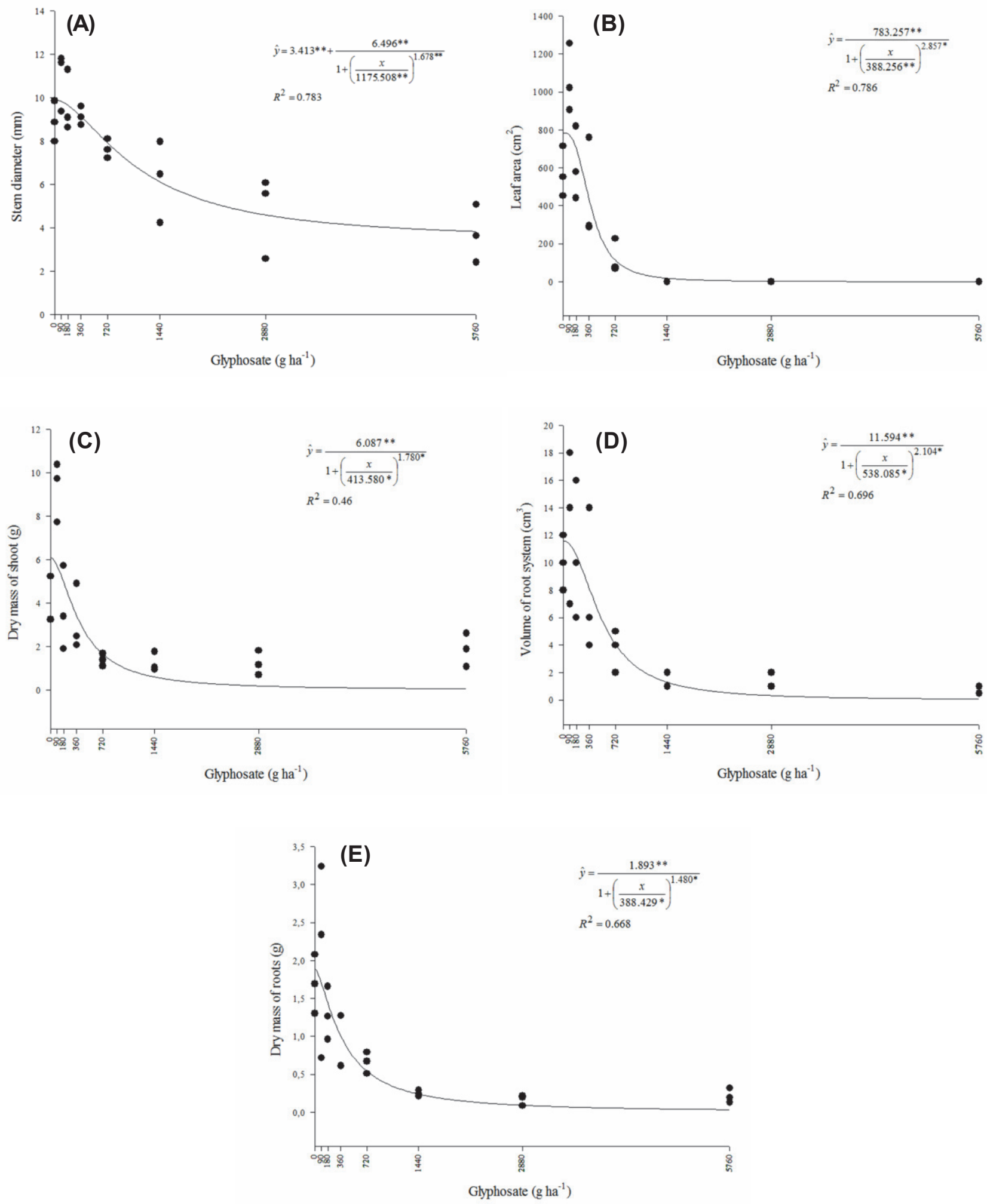

** and *: significant at 1 and $5 \%$ probability, respectively.

Figure 2 - Dose-response curves on the characteristics of stem diameter (A), leaf area (B) dry mass of shoot (C), volume of the root system (D) and dry mass of roots (E) of castor bean plant at 21 days after the application of glyphosate. 
of castor bean volunteer plant after the installation of the culture, once new studies are necessary to determine the combinations of doses in sequence and more appropriate interval between applications. Another possibility to be considered would be the application of glyphosate in the pre-sowing (desiccation), alone or combined with other herbicides, as measured in the first experiment, followed by one or more applications of glyphosate after soybean emergence. However, within management strategies, it is necessary to consider the exception for the importance of rotating and/ or combining the use of action mechanisms alternative for the inhibition of EPSPs whenever possible, either in pre or post-seeding, in order to avoid the emergence of biotypes of glyphosate-resistant weeds.

Mckeon and Brichta (2014) found that glyphosate $\left(800 \mathrm{~g} \mathrm{ha}^{-1}\right)$ applied at 35 days after emergence (DAE) controlled $47 \%$ of castor bean plant at 42 DAA. In later applications, held on 63 and 91 DAE, it was only observed $15 \%$ of mortality in castor bean plant at 49 DAA, indicating increased susceptibility of the young plants. However, both the earlier application as later caused effect on the reproductive capacity of the castor bean plant, with the death of more than $96 \%$ of inflorescences and reduced germination of the seeds superior to $95 \%$, which features relevant preventive action to avoid the increasing of the seed bank of that specie.

Adjusting of the log-logistic model of the dose-response curve for the stem diameter resulted in one of the lowest values for the parameter $b$ and the highest dose corresponding to $\mathrm{I}_{50}\left(1,175 \mathrm{~g} \mathrm{ha}^{-1}\right)$, in relation to other characteristics evaluated, indicating low response of that variable to the herbicide dose (Figure 2A). This information corroborates the finding of no effect of glyphosate on the stem diameter in the first experiment. For the leaf area (Figure 2B), the effect of glyphosate showed itself very significant, presenting one of the largest slope of the curve (parameter $b$ ) and one of the smallest values of $I_{50}$ (388 $\mathrm{g} \mathrm{ha}^{-1}$ ), resulting from the adjustment to the logistic model compared to other evaluated characteristics. The trend of stabilization of glyphosate dose on the leaf occurred from $720 \mathrm{~g} \mathrm{ha}^{-1}$, similar to that observed for control and height of plant (Figure 1A and B, respectively).

The adjustment of the logistic model of the dose-response curve for dry mass of shoot resulted in value of $\mathrm{I}_{50}\left(412 \mathrm{~g} \mathrm{ha}^{-1}\right)$ close to what was noticed on the leaf area, confirming the similar interference for this variable (Figure $2 \mathrm{C})$. Similarly, the proximity of values of the doses of 538 and $388 \mathrm{~g} \mathrm{ha}^{-1}$ corresponding to $\mathrm{I}_{50}$ resulting from the model adjustments for volume and dry mass of the roots (Figure 2D and $2 \mathrm{E}$ ) indicates the interdependence between those characteristics as well as the direct relationship between the growth of the shoot and the growth of the roots in the early stages of castor bean plant. For dry mass of shoots and roots, and the volume of the root system, the trend of interference stabilization occurred between 720 and $1,440 \mathrm{~g} \mathrm{ha}^{-1}$. Therefore, the results of the second experiment confirm those obtained in the first, in which the glyphosate applied alone in intermediate dose $\left(1,080 \mathrm{~g} \mathrm{ha}^{-1}\right)$ provided reductions of more than $80 \%$ on the leaf area, on the volume of the root system and on the dry mass of the shoot and roots.

From the results, the applications of diuron (300 $\left.\mathrm{g} \mathrm{ha}^{-1}\right)$ combined with paraquat $\left(600 \mathrm{~g} \mathrm{ha}^{-1}\right)$ and glyphosate $\left(1,080 \mathrm{~g} \mathrm{ha}^{-1}\right)$ associated with 2,4-D (670 $\left.\mathrm{g} \mathrm{ha}^{-1}\right)$, carfentrazoneethyl (20 $\left.\mathrm{g} \mathrm{ha}^{-1}\right)$, flumioxazin (25 $\left.\mathrm{g} \mathrm{ha}^{-1}\right)$ or saflufenacil (35 $\left.\mathrm{g} \mathrm{ha}^{-1}\right)$ were the most efficient options for castor bean control in the desiccation of pre-sowing of soybean crop. Glyphosate applied from $720 \mathrm{~g} \mathrm{ha}^{-1}$ in postemergence soybean crop was effective in controlling the castor bean plant.

\section{ACKNOWLEDGEMENTS}

The study reported in this paper was supported by Embrapa (Empresa Brasileira de Pesquisa Agropecuária [Brazilian Agricultural Research Corporation], funded by the Ministry of Agriculture, Livestock and Food Supply. The authors also thank CNPq [Conselho Nacional de Desenvolvimento Científico e Tecnológico (National Counsel of Technological and Scientific Development)] by the scholarships provided for the first and last author. 


\section{LITERATURE CITED}

Brasil. Ministério da Agricultura, Pecuária e Abastecimento. Agrofit. Acesso em: 15 maio 2015. Disponível em: http:// extranet.agricultura.gov.br/agrofit_cons/ principal_agrofit_cons..

Campbell D.N. et al. Developing a castor (Ricinus communis L.) production system in Florida, US: evaluating crop phenology and response to management. Ind Crops Prod. 2014;53:221-7.

Companhia Nacional de Abastecimento - Conab. Mamona série histórica. Acesso em: 17 ago. 2015. Disponível em: http://www.conab.gov.br.

Correia N.M., Durigan J.C. Controle de plantas daninhas na cultura de soja resistente ao glyphosate. Bragantia. 2010;69:319-27.

Costa A.G.F. et al. Weed management strategies for castor bean crops. Acta Sci Agron. 2014;36:135-45.

Empresa Brasileira de Pesquisa Agropecuária Embrapa. Sistema brasileiro de classificação de solos. $3^{\mathrm{a}}$. ed. Brasília: 2013.353p.

Food and Agriculture Oganization of United Nations - FAO. Food and Agricultural commodities production. Acesso em: 17 ago. 2015. Disponível em: http://faostat3.fao.org.

Foloni S. et al. Dessecação química em pré-colheita da mamona. Rev Ceres. 2011;58:665-9.

Gordon D.R. et al. Assessing the invasive potential of biofuel species proposed for Florida and the United States using the Australian Weed Risk Assessment. Biomass Bioen. 2011;35:74-9.

Mckeon T.A., Brichta J. Effect of glyphosate on the castor plant Ricinus communis L. Biocatalysis Agric Biotechnol. 2014;3:397-9.

Medeiros K.A.A. et al. Tolerância de mamoneira ao herbicida trifluralin em solos com diferentes texturas. Rev Bras Eng Agríc Amb. 2013;17:1333-9.

Minozzi G.B. et al. Eficácia de diferentes manejos de plantas daninhas na cultura da soja transgênica. Agrária. 2014;9:40612 .
Monquero P. et al. Saflufenacil no controle de Luffa aegyptiana, Merremia cissoides, Mucuna aterrima e Ricinus communis. Rev Bras Herb. 2011;10:176-82.

Rizzardi M.A., Silva L. Manejo de plantas daninhas eudicotiledôneas na cultura da soja Roundup Ready ${ }^{\circledR}$. Planta Daninha. 2014;32:683-97.

Seefeldt S.S. et al. Log-Logistic analysis of herbicide dose response relationships. Weed Technol. 1995;9:218-27.

Severino L.S. et al. A review on the challenges for increased production of castor. Agron J. 2012;104:853-80.

Severino L. S. et al. Método para determinação da área foliar da mamoneira. Rev Bras Oleag Fibr. 2004;8:753-62.

Silva M.T.H. et al. Enraizamento de estacas de pitaya vermelha em diferentes substratos. Rev Caatinga. 2006;19:61-4.

Silva P.V.C. Controle químico e influência da palha de cana-de-açúcar e da profundidade de semeadura na emergência de plantas daninhas [tese]. Araras: Universidade Federal de São Carlos, 2013.

Sociedade Brasileira da Ciência das Plantas Daninhas SBCPD. Procedimentos para instalação, avaliação e análise de experimentos com herbicidas. Londrina: 1995. $42 p$.

Sofiatti V. et al. Pre and post-emergence herbicides for weed control in castor crop. Ind Crops Prod. 2012;37:235-7.

Soratto R.P. et al. Narrow row spacing and high plant population to short height castor genotypes in two cropping seasons. Ind Crops Prod. 2012;35:244-9.

Soratto R.P. et al. Espaçamento e população de plantas de mamoneira de porte baixo para colheita mecanizada. Pesq Agropec Bras. 2011;46:245-53.

Takano H.K. et al. Efeito da adição do 2,4-D ao glyphosate para o controle de plantas daninhas de difícil controle. Rev Bras Herb. 2013; 12:1-13.

Vitorino H.S. et al. Eficiência de herbicidas no controle de plantas daninhas latifoliadas em mamona. Arq Inst Biol. 2012;79:127-31. 